\title{
Woodland rehabilitation and biodiversity conservation in an agricultural landscape in south eastern Australia
}

\section{MIRIAM ADAMS-SCHIMMINGER ${ }^{1}$, GRAHAM FIFIELD ${ }^{2}$, BRUCE DORAN ${ }^{1}$ AND DAVID FREUDENBERGER ${ }^{1}$}

${ }^{1}$ Fenner School of Environment and Society, Australian National University, Canberra, Australia, ${ }^{2}$ Greening Australia, Jamison, Australia

Email: David.freudenberger@anu.edu.au

\begin{abstract}
Southern Australia has a tree crisis. The iconic and ecologically essential eucalypt trees are dying out across vast swathes of farmland that were once grassy woodlands. A century of clearing and agricultural intensification, plus the failure of these trees to self-regenerate, has led to a massive loss of wildlife habitat, particularly tree hollows that only form in large and old Eucalyptus trees. Just as importantly, this decline in trees has exposed farmers to losses of agricultural productivity. There is now a lack of shelter for livestock. Rising salty ground water is degrading pastures as this ground water is no longer being controlled by the deep roots and respiration of eucalypts. We describe the research that shows how an innovative partnership between farmers, a non-government environmental organisation, and government funding is rehabilitating entire fields to a productive and wildlife-rich woodland full of thriving eucalypts.
\end{abstract}

\section{LEARNING OUTCOMES}

This case study is an example of the benefits of a sustained and diverse collaboration between farmers, a non-government environmental organisation, a variety of researchers with complementary skills, and with support from national government funding programmes. This collaboration is achieving remarkable results. It is greatly enhancing the conservation of biodiversity, as well as improving commercial farm productivity and sustainability. This case study provides a solution to a global challenge faced by all societies dependent on agriculture-sustainable farming and cost-effective biodiversity conservation in the same place.

\section{CLASSROOM TESTED? NO}

\section{INTRODUCTION}

There is a tree crisis in southern Australia. Trees have been extensively cleared to make room for intensive agricultural production-lots of cultivated pastures, crops, and livestock [I]. The few trees that remain are rapidly dying of old age and diseases (Figure ra). Critically these trees are not regenerating from seed naturally cast by the parent tree [2]. Yet Australia is the evolutionary home of over 800 species of eucalyptus trees that provide habitat for a myriad of organisms from microbes to thousands of species of insects, as well as the birds that feed upon these insects. These farmland trees are also the home for many small marsupials and bats that find shelter amongst the bark, or nest in the hollows that form in trees over 100 years old [3]. As well, this loss of hardy and deep-rooted eucalypt trees is contributing to vast outbreaks of dryland salinity (Figure $\mathrm{ib}$ ) caused by rising saline water tables that are no longer being suppressed by the respiration (pumping) services of woodland eucalypts [4].

For the past 30 years this crisis has been recognised by researchers, conservationists, farmers, and government agencies. But most efforts to re-establish locally native eucalypt trees and their associated Acacia mid-story and diverse ground flora have failed to meet the spatial challenge of the vast loss of trees across Australian farmland. For over three decades, farmers, with the help of government programmes, and their neighbours (Landcare groups) have been planting a few rows of trees along the border of their fields and revegetating the unproductive parts of the farm (erosion

Case Studies in the Environment, 2017, pps. I-I4. electronic ISSN 2374-538X. (C) 2017 by the Regents of the University of California. All rights reserved. Please direct all requests for permission to photocopy or reproduce article content through the University of California Press's Reprints and Permissions web page, www.ucpress.edu/journals.php?p=reprints. DOI: https://doi.org/10.1525/cse.2017.sc.399598 

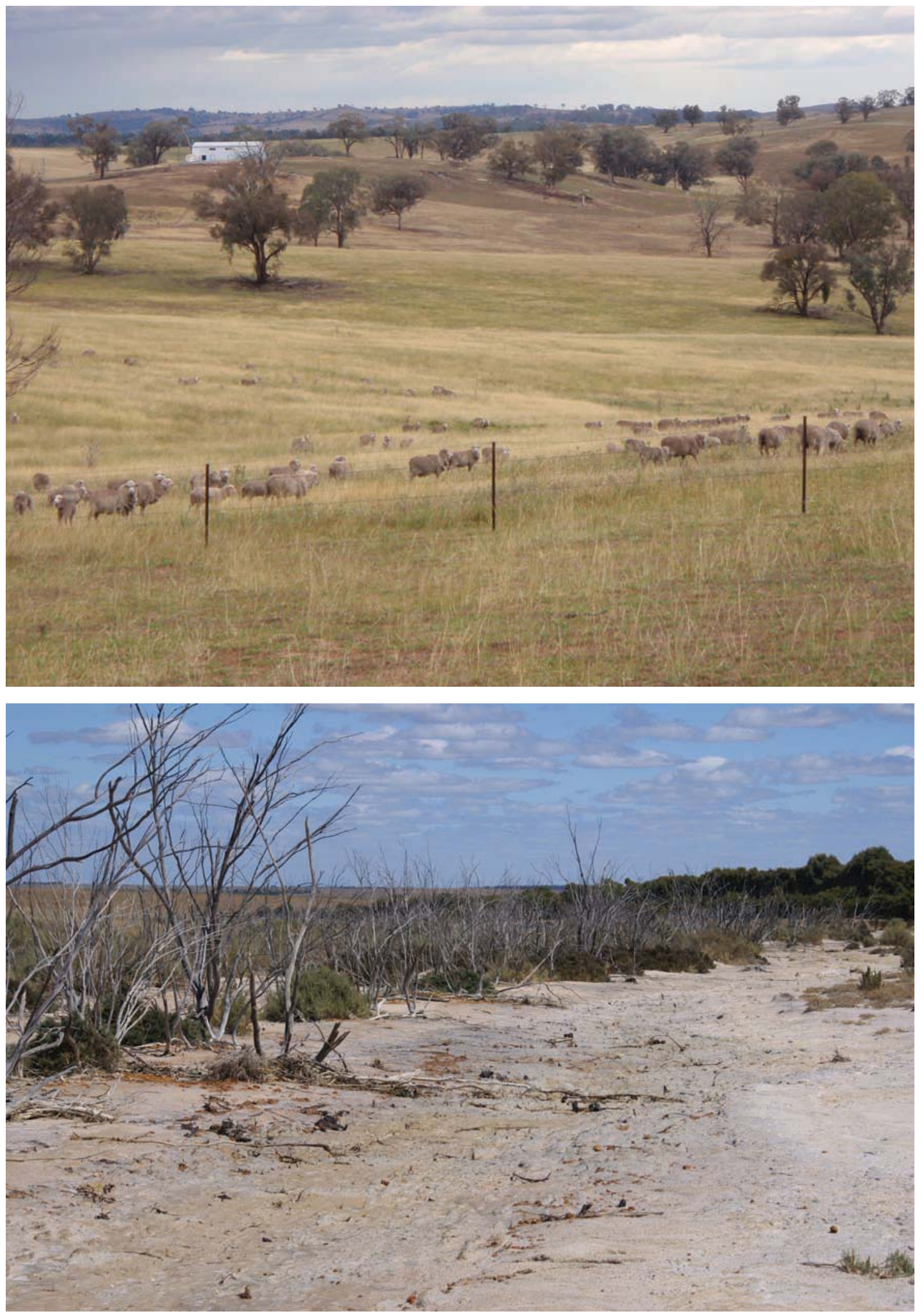

FIGURE 1. The Australia tree crisis. A) Much of southeast Australia has just a scatter of old eucalypt trees; natural recruitment of young trees is suppressed by livestock grazing. B) Loss of deep-rooted eucalypt woodlands has resulted in outbreaks of dryland salinity, particularly in Western Australia. 


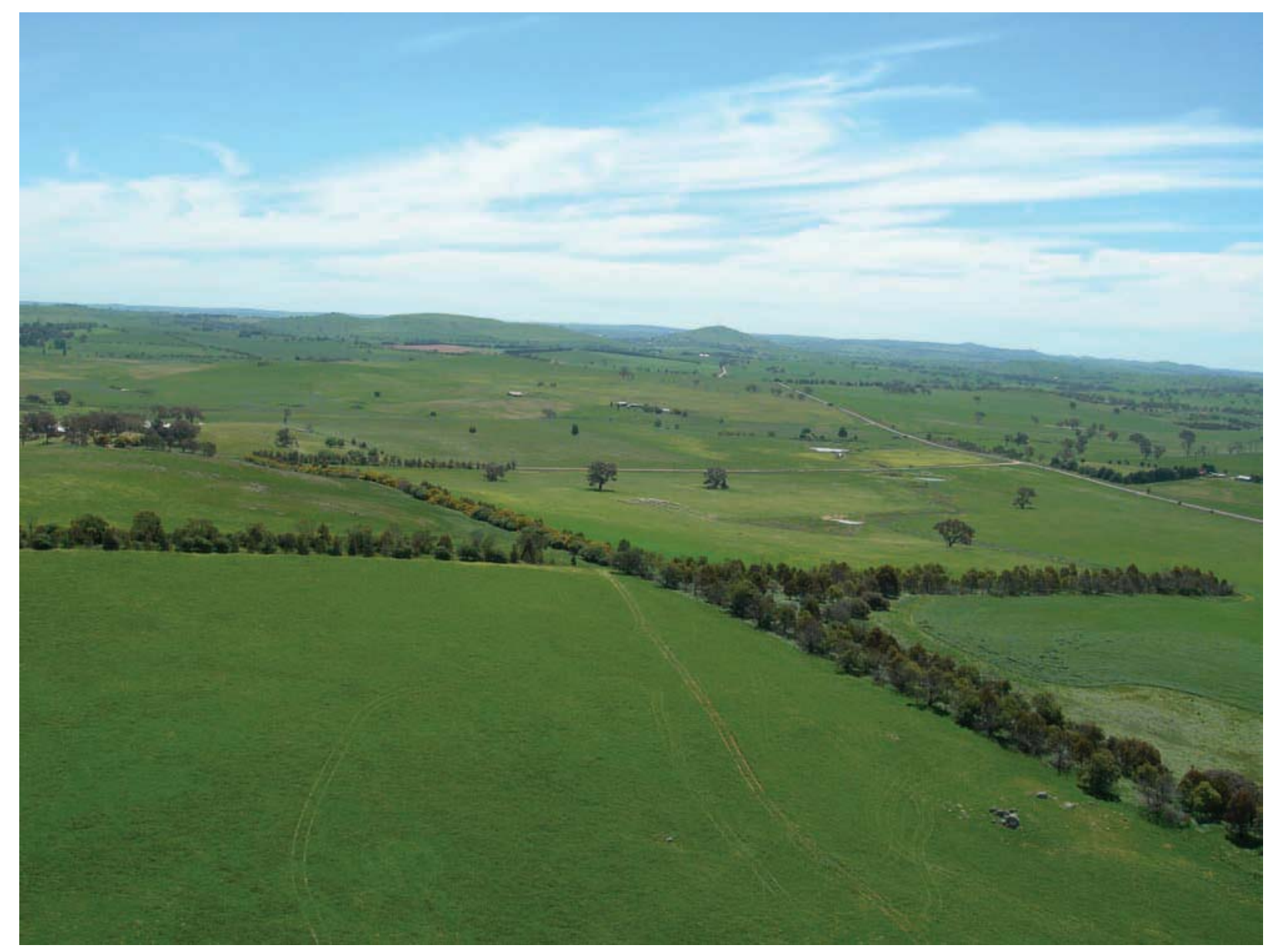

FIGURE 2. In places there are these linear plantings of native woodland trees and shrubs, great for shelter for farmer's livestock and crops, but insufficient in size for quality wildlife habitat. Such plantings are expensive as they must be fenced on both sides to protect them from livestock grazing.

gullies, saline land, and rocky hilltops). But these relatively tiny green patches scattered across vast farming lands (Figure 2) simply cannot provide enough habitat for native wildlife, and not enough pumping power to control saline ground water from breaking out and creating salty dead zones.

Yet removing farmers and fully restoring all their land back to woodlands and forests is not an option. All of us city folks are dependent on farmland and hard-working farmers. We can't turn the clock back to hunting and gathering as the first Australians (over 200 Aboriginal nations) did for 60,000 years. Much of their ingenious food gathering strategies have been lost (often killed-off), and such practices only supported at most i million people [s]. Australia now supports 23 million inhabitants and feeds another 40 million people through food exports.
Australia has many millions of hectares of national parks and other conservation reserves. Their beauty and diversity are truly impressive, but they are not fully representative nor comprehensively conserve all types of ecosystems. Australia's conservation estate only includes a few thousand hectares of grassy eucalypt woodlands that once covered millions of hectares in south eastern Australia. In reality, there's not much left to conserve since more than $95 \%$ of grassy eucalypt woodlands have been cleared or greatly modified for agriculture. This poses a significant challenge. Can we have both our food and our unique woodland flora and fauna? Is it possible?

\section{CASE EXAMINATION}

This is a good news story. Yes we can. Yes, it is possible to produce silky fine wool, tasty lamb chops, and provide 
enduring habitat for Australia's stunning and unique wildlife.

\section{A solution-Whole of Paddock Rehabilitation (WOPR)}

This innovative agri-environment scheme re-establishes a diversity of locally native trees and shrub species on many dozens of farms in the region surrounding Canberra, Australia's capital city. A form of WOPR is also being rolled-out across the wheat fields of Western Australia. WOPR is primarily funded through national government programmes administered by Greening Australia, an environmental non-government organisation (NGO). Funding has been received courtesy of the NSW Lachlan Catchment Management Authority (now Local Land Services), the federal government's Caring for our Country programme, the federal government's Biodiversity Fund, and the NSW Department of Environment and Climate Change through the Kosciuszko2 Coast initiative. These programmes funded the cost of re-vegetation (seed, labour, fencing-where required) and the stewardship payments which we will expand on shortly. In-kind support to promote the programme and help identify sites was received from various Catchment Management Authorities and Landcare groups. This kind of funding is nothing new. Various government programmes, facilitated by farmer groups and NGOs, have been funding tree planting on farms in Australia for more than 30 years [6]. What makes WOPR unique is the scale and configuration of plantings. Rather than a farmer or government funders having to spend up to $\$ 10,000 / \mathrm{km}$ on fencing to create narrow ( $\leq 25 \mathrm{~m}$ wide) plantings along the boundaries of fields, WOPR is applied to existing fields at least ro ha in size, often fenced many decades ago. A mix of native tree and shrub species are direct seeded along rows $5 \mathrm{~m}$ apart. Four rows constitute a belt, and belts are at least $40 \mathrm{~m}$ apart (Figure 3). Typically, 25-30\% of the paddock (field) is returned to trees and shrubs. These wide gaps allow sheep grazing to continue in the paddock once the trees and shrubs are large enough to tolerate grazing (about 5 years).

WOPR is a partnership between Greening Australia and the farmers who have volunteered to participate in the programme-it's their land and they are responsible for weed control prior to planting, vermin control, and keeping their livestock out. The Australian Government funds Greening Australia to do the direct seeding with simple, yet specialised machinery towed by a $4 \mathrm{WD}$ vehicle. Greening Australia also administers, on behalf of the
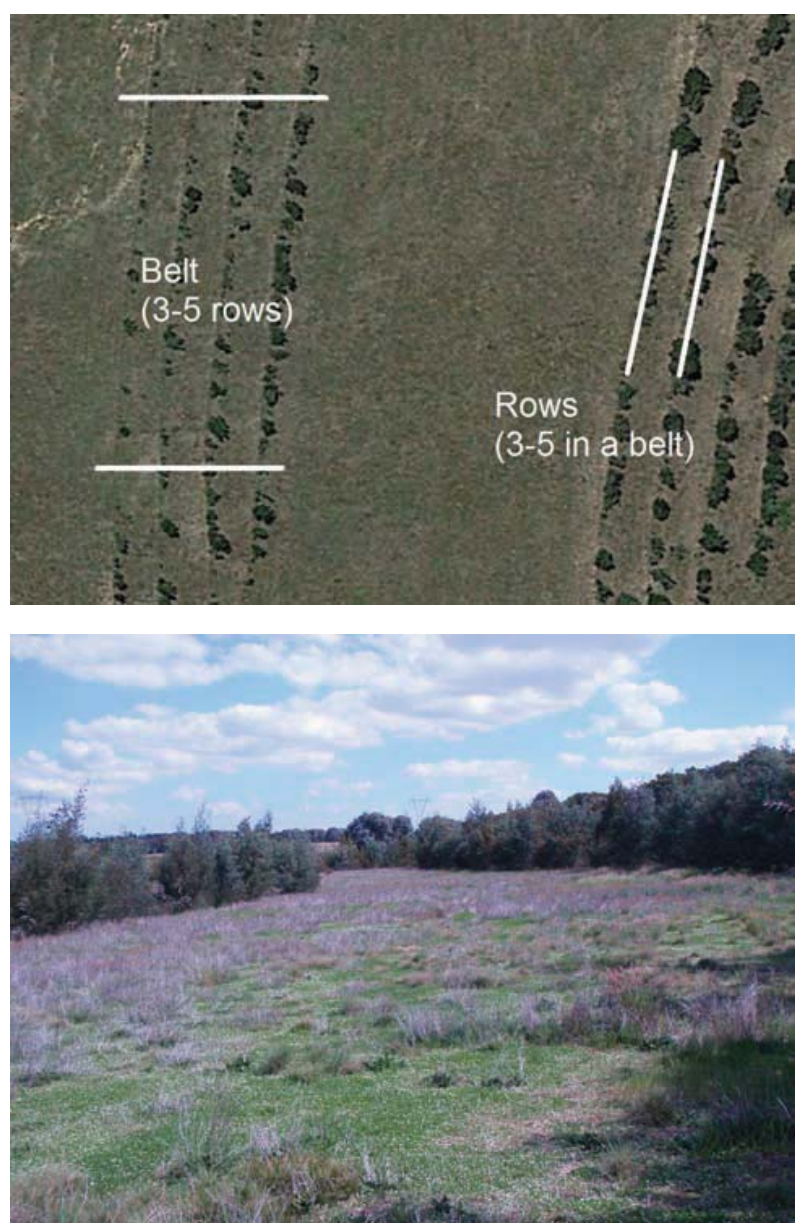

FIGURE 3. A) A typical Whole of Paddock Rehabilitation (WOPR) paddock clearly shows the structure of the direct seeding. A mixture of trees and shrubs are directed seeded along the contours in rows that are $5 \mathrm{~m}$ apart. Three to five rows make up a belt, and these are at least $40 \mathrm{~m}$ apart. Image: Google Earth. B) A typical WOPR planting on the ground looking between belts of trees. The area within and between belts is available for sheep grazing once the trees are tall enough (about 5 years).

Government, modest funding to the farmer to help off-set the financial burden of not grazing the WOPR paddock for five years. These are referred to as 'stewardship payments'.

As an agri-environmental scheme, WOPR is designed to deliver a range of environmental (public good) benefits. It is expected that WOPR paddocks will provide diverse habitat patches across the agricultural landscape for native wildlife, such as those birds that require large (greater than io ha) expanses of grassy woodland [7]. The diversity of small Acacia trees and shrubs that are included in the 


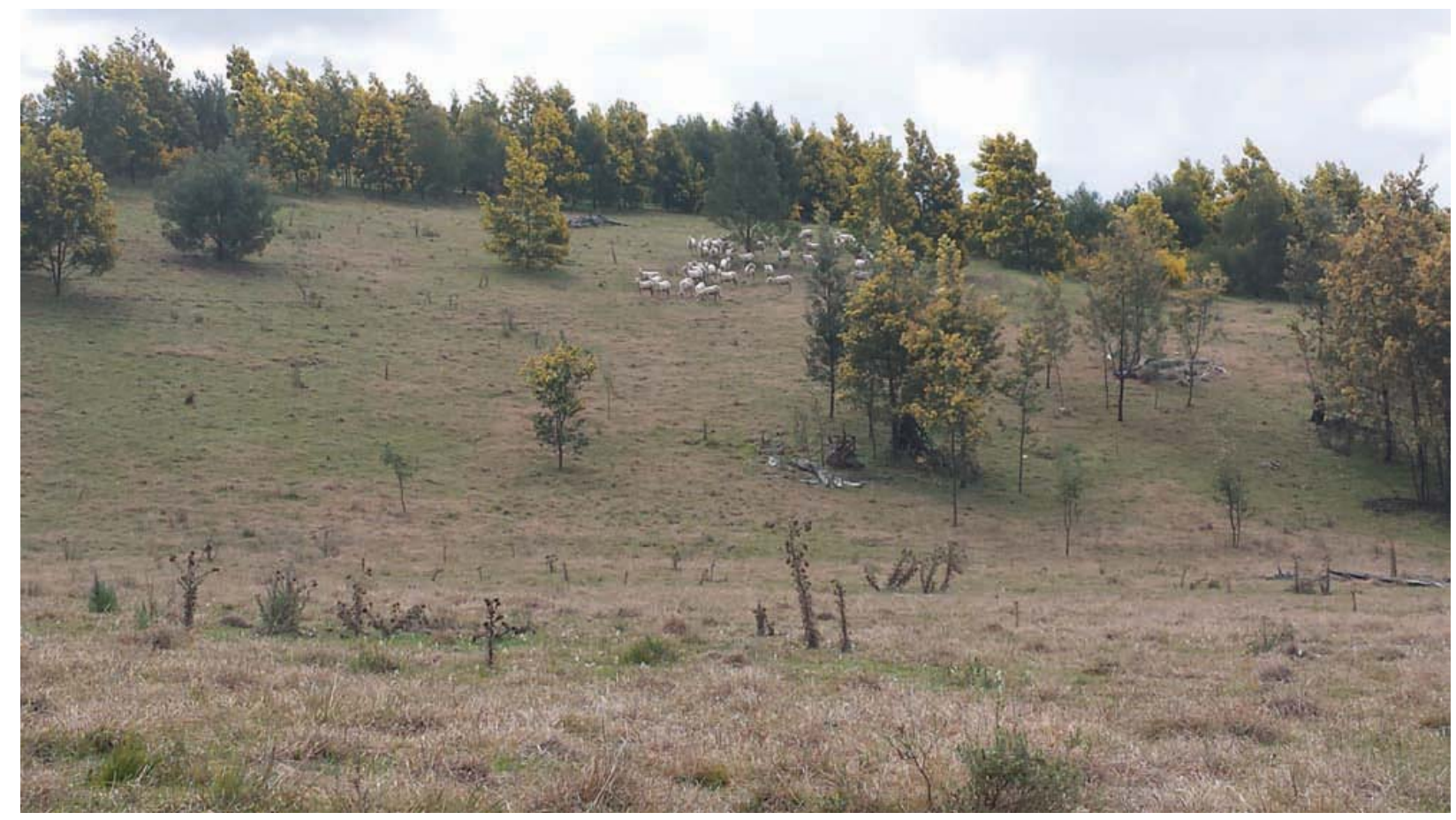

FIGURE 4. Most Whole of Paddock Rehabilitation (WOPR) paddocks have been planted to a diversity of Acacias (in yellow bloom) that grow rapidly, quickly providing shelter and nutritious browse for sheep, but they only live for a few decades where the eucalypts hidden amongst these Acacias can survive for centuries.

seed mix provides dense habitat and food for insectivorous birds, which are often those of conservation concern [8]. It is only the eucalypt trees that live long enough, typically hundreds of years, to have different sized tree hollows. These holes and caverns within the tree are formed by storms breaking off branches which attract fungi and termites that accelerate internal branch and trunk decay. Hollows are essential nesting spots of many different kinds of birds, bats, and marsupials unique to Australia's woodlands [9].

\section{Is it working?}

The pinhead-sized seeds of eucalypts are in nearly every seed mix sown across WOPR paddocks, but their germination and establishment is problematic. Eucalypt seeds are sown on or near the surface $(0-5 \mathrm{~mm})$ into a cultivated and loosened seedbed and simply pressed down into mineral soil with a wheel attached to the seeder. These tiny and expensive seeds have to survive predation by ants, and may not get enough rainfall to germinate for months. If they germinate, then they must compete with weeds, predation from herbivores, and competition from Acacias and shrubs that often establish and grow much more vigorously.
Even 3-4 years after planting, it can be hard to see the eucalypt trees amongst a thicket of colourful Acacias (Figure 4).

So our first research question was, are the eucalypts there amongst all the other woody species, and if so, how may? Simple question, but hard work to answer. It took a team to answer this simple question. The most important members of the team were the friendly farmers who welcomed us onto their WOPR paddocks to have a good look around. But who were these farmers? What's their phone numbers and email addresses? This is where Graham from Greening Australia came in. This is a trusted NGO with loyal staff like Graham who have built up long and enduring relationship with the farmers they work with. Field research of this kind requires social capital. Greening Australia provided the critical introduction to the farmers we wanted to visit and the paddocks we wanted to hike all over, as well as information about what woody species were sown, how much seed per kilometre, and when it was sown. Simple data, but often lost if project management systems aren't up to scratch and well archived.

The third part of our research team was Miriam, a keen fourth year university student seeking to do an Honours 
project (9 months of research and thesis writing). Miriam was the field researcher who did all the phone calls, met all the farmers, and surveyed every eucalypt tree across nine WOPR paddocks (Figure 5). She wasn't able to identify the actual species of each young eucalypt tree as one often needs to look at the shape of the seed capsule (fruit) to be confident of species IDs. So she recorded the GPS location of $\mathrm{I} 6,000$ eucalypts along hundreds of kilometres of seeded rows across a total of 200 ha. Quality research requires replication (lots of sites, belts, rows, and ha) and replication is lots of work.

The fourth part of our research team were Miriam's academic supervisors with a complement of expertise. David was the restoration ecologist familiar with WOPR and the challenges of conducting field work at such a scale. Bruce was the spatial socio-ecologist, experienced in using GIS to better understanding ecological processes at multiple scales and how GIS can inform and guide complex natural resource management decisions. Bruce's advice and guidance were needed to visualise the data. Numbers tell important stories. Numbers provide statistical validity to our conclusions. But data visualisation helps communicate results and facilitate understanding.

Table I tells the numbers story. WOPR paddock sizes were relatively big, on average $22 \mathrm{ha}$. There were very few old paddock trees that have survived iso years of clearing and farming. Strikingly, the establishment of young eucalypts from the sown seed was highly variable. From as few as Is trees/ha to as many as $5,000 / \mathrm{ha}$. This variation was also found within rows ( $159-665$ trees $/ \mathrm{km})$ and across the belts of trees $(237-2,389$ trees $/ \mathrm{km}$ of belt).

But it's hard to visualise what these numbers look like on the ground. This is where an inexpensive GPS was so useful. Since every eucalypt location was recorded by the GPS, each could be imported into a GIS and mapped. Figures 6-14 provide the visual story of the remarkably patchy establishment of eucalypts from the scale of metres within rows, between rows, between belts, and between the nine different WOPR paddocks. Rhino software (Version 5) was used to take each individual point (tree) and assign it to a row and belt. Kernel Density estimation algorithms in ArcGIS (vio.3.I) were then used to transform this point data into continuous data with a fine array of pixels to then apply colour coding to generate 'heat maps' (Figures 6-14) [10]. We have purposefully applied a unique colour scheme (tree density classes) for each map (WOPR paddock) to visualise the spatial patterns, namely hot-

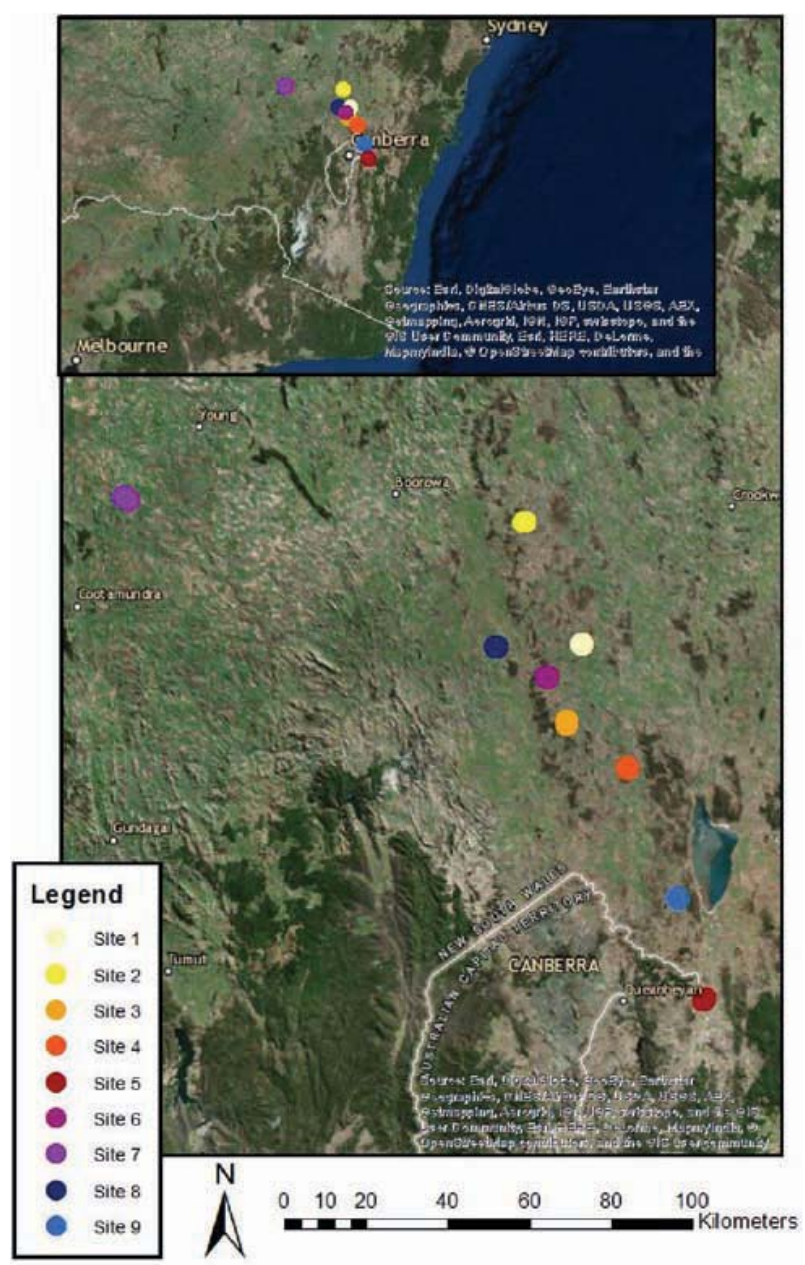

FIGURE 5. The nine study sites were largely to the north of Canberra, in the south-east corner of Australia (inset).

spots', of eucalypt tree density within each unique WOPR paddock.

\section{Why so variable?}

As ecologists, we continuously ask the 'why' question. In this case, why have the eucalypts established in such a patchy (variable) manner? It would probably take a lifetime or two to fully answer this question, but we know enough to pose some reasons (hypotheses) of the possible causes or drivers of this variation in tree density. Australia is an awfully dry place with highly variable rainfall from month to month and year to year. So an obvious hypothesis is that rainfall (or the lack of it) may explain some of the tree density variation between WOPR paddocks. This does appear to be the case (Figure 15). Statistical analysis of this variance in tree density across paddocks indicated a very high $(p>0.00 \mathrm{I})$ probability that more trees established 
TABLE 1. Eucalypt densities between the nine Whole of Paddock Rehabilitation (WOPR) sites was highly variable, and was variable at different scales within the sites.

\begin{tabular}{|c|c|c|c|c|c|c|}
\hline Site & $\begin{array}{l}\text { Size } \\
\text { (ha) }\end{array}$ & $\begin{array}{l}\text { Old and } \\
\text { self- } \\
\text { recruiting } \\
\text { trees }\end{array}$ & $\begin{array}{l}\text { Total } \\
\text { WOPR } \\
\text { eucalypts } \\
\text { (planted) }\end{array}$ & $\begin{array}{l}\text { Density } \\
\text { WOPR } \\
\text { eucalypts/ } \\
\text { ha }\end{array}$ & $\begin{array}{l}\text { WOPR } \\
\text { eucalypts } \\
/ \mathrm{km} / \text { row }\end{array}$ & $\begin{array}{l}\text { WOPR } \\
\text { eucalypts } \\
/ \mathrm{km} / \text { belt }\end{array}$ \\
\hline 1 & 15 & 22 & 5,543 & 370 & 665 & 2,389 \\
\hline 2 & 17 & 4 & 2,869 & 169 & 457 & 1,506 \\
\hline 3 & 18 & 48 & 2,476 & 138 & 247 & 778 \\
\hline 4 & 25 & 2 & 1,432 & 57 & 161 & 401 \\
\hline 5 & 25 & 15 & 1,127 & 45 & 171 & 426 \\
\hline 6 & 20 & 5 & 871 & 44 & 159 & 444 \\
\hline 7 & 30 & 10 & 767 & 26 & 187 & 237 \\
\hline 8 & 35 & 10 & 533 & 15 & 231 & 427 \\
\hline 9 & 14 & 25 & 458 & 33 & 355 & 684 \\
\hline Mean & 22 & 16 & 1,786 & 100 & 293 & 810 \\
\hline $\begin{array}{l}\text { Standard } \\
\text { deviation }\end{array}$ & 7 & 14 & 1,641 & 114 & 172 & 700 \\
\hline
\end{tabular}

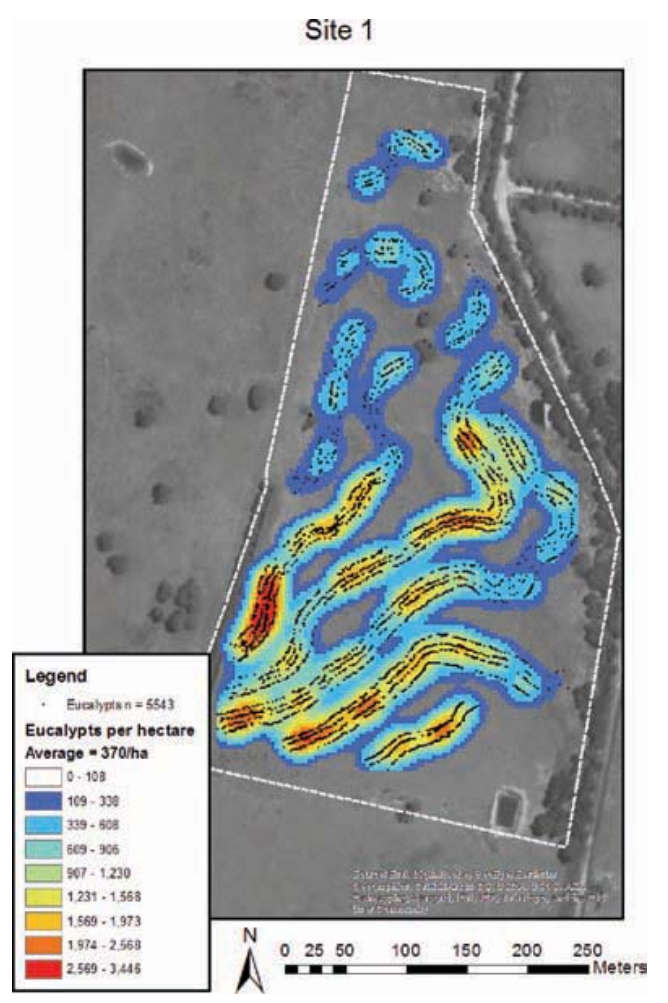

FIGURE 6. Site I is is ha in size, had an average density of 370 eucalypts/ha, and a range of $0-3,446$ eucalypts/ha.

in above average years compared to years with below average rainfall.

We also found that there was a higher probability $(p<0.001)$ that more trees established near pre-existing

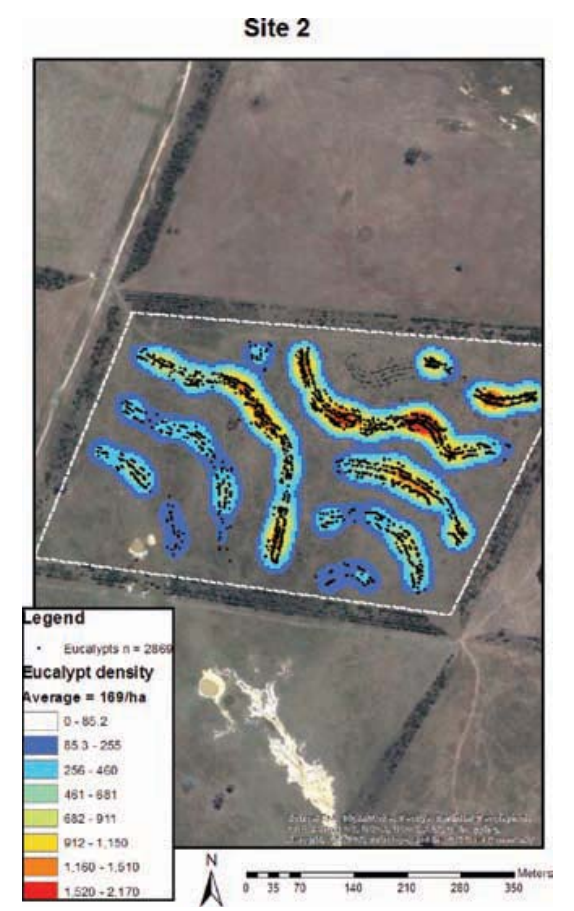

FIGURE 7. Site 2 is 17 ha in size, had an average density of 169 eucalypts/ha, and a range of $0-2,170$ eucalypts/ha. Note the severe gully erosion to the south of this Whole of Paddock Rehabilitation (WOPR) paddock.

(mature age) shelter belts compared to well away from shelter belts (Figure 16). This spatial pattern may be due to warmer winter temperatures (less damaging frosts) and less desiccation (water loss) near these shelter belts. 


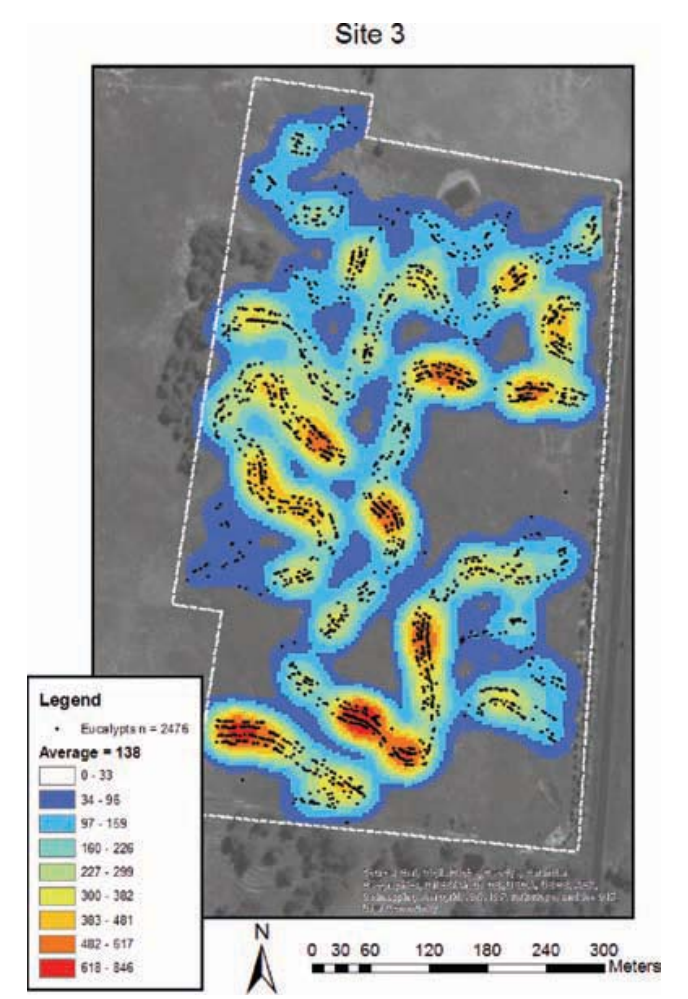

FIGURE 8. Site 3 was 18 ha in size, had an average density of 138 eucalypts/ha, and a range of o-846 eucalypts/ha.

Site 4

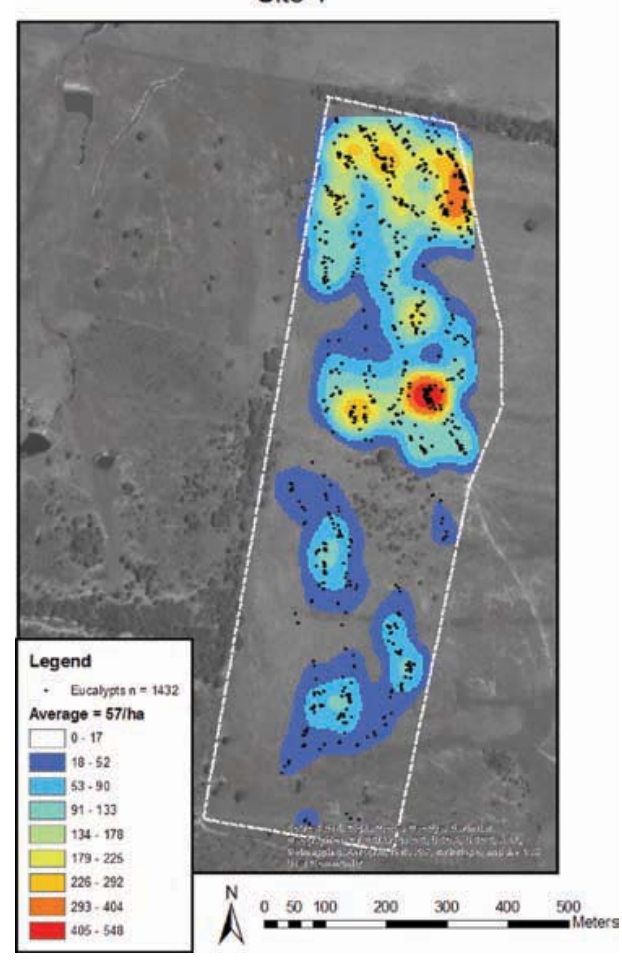

FIGURE 9. Site 4 is 25 ha in size, had an average density of 57 eucalypts/ha, and a range of $0-548$ eucalypts/ha.

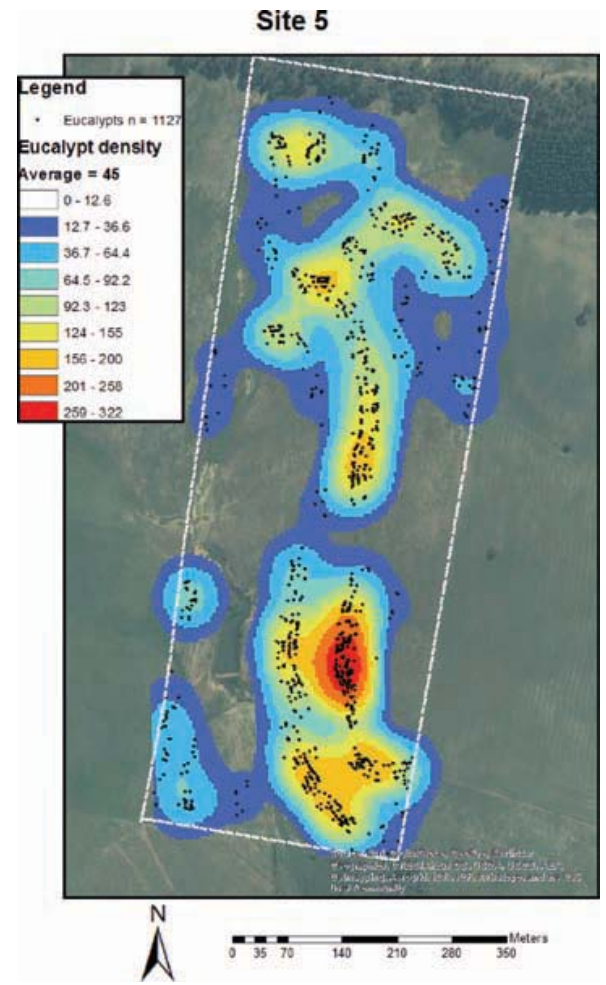

FIGURE 10. Site 5 is 25 ha in size, had an average density of 45 eucalypts/ha, and a range of o-322 eucalypts/ha.

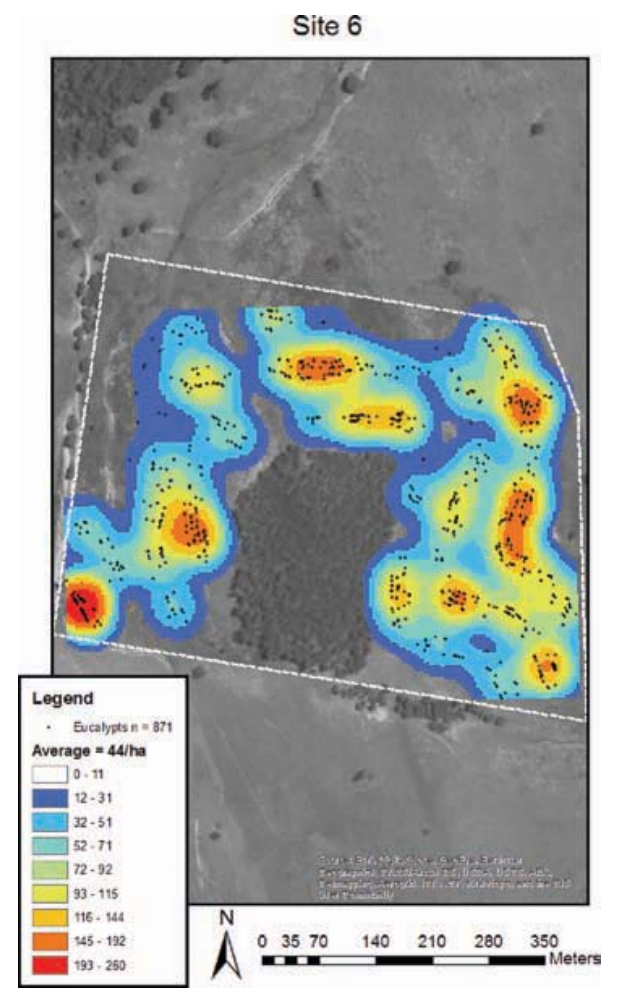

FIGURE 11. Site 6 is 20 ha in size, had an average density of 44 eucalypts/ha, and a range of $0-260$ eucalypts/ha. 


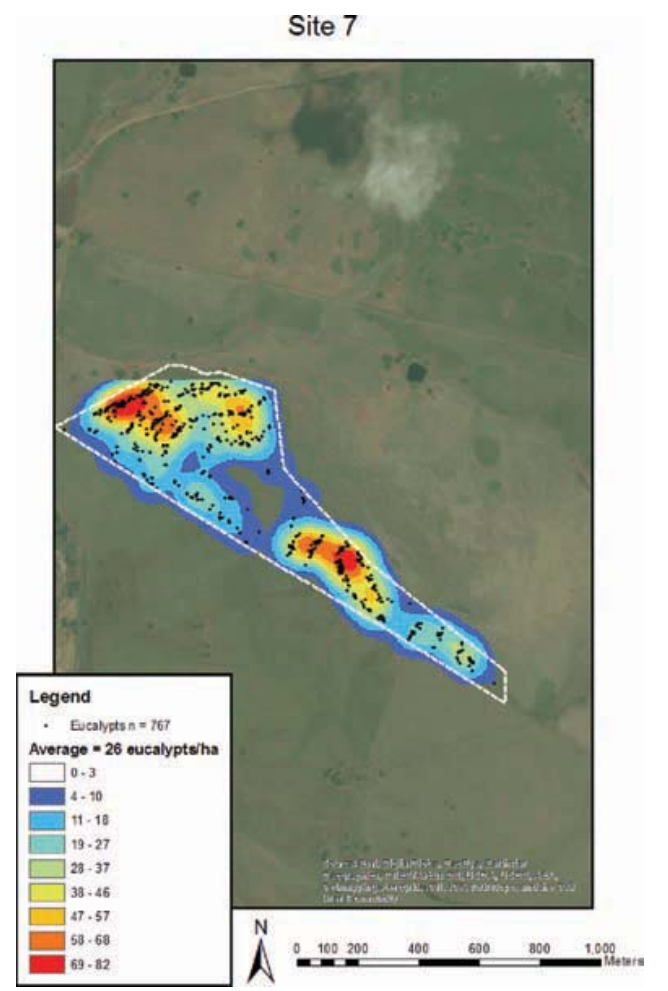

FIGURE 12. Site 7 was 30 ha in size, had an average density of just 26 eucalypts/ha, and a range of $0-82$ eucalypts/ha.

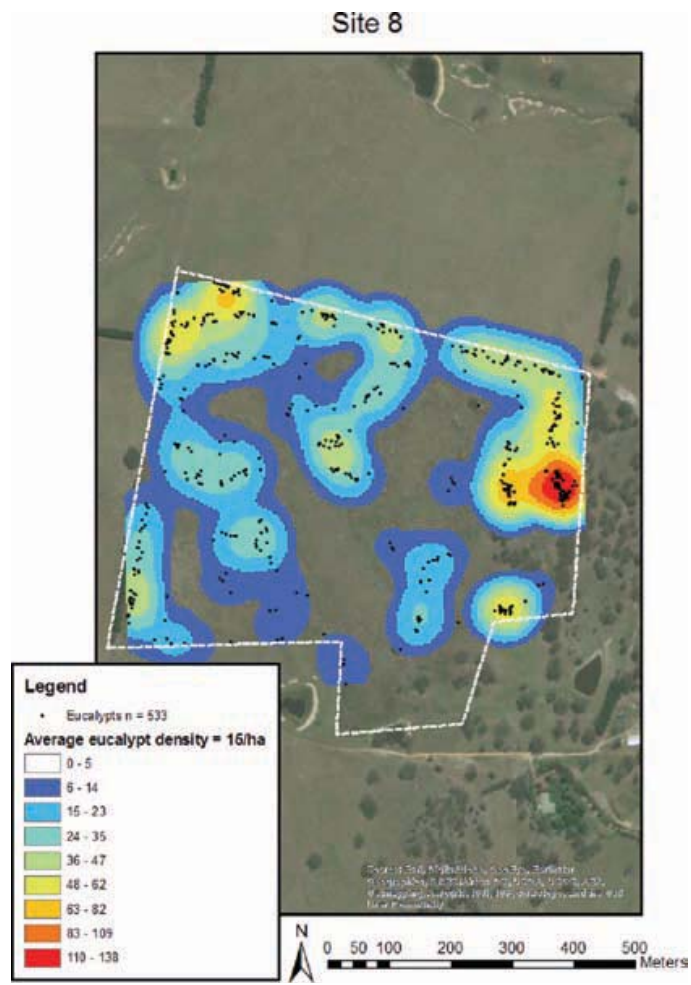

FIGURE 13. Site 8 is 35 ha in size, had an average density of Is eucalypts/ha, and a range of $0-138$ eucalypts/ha.

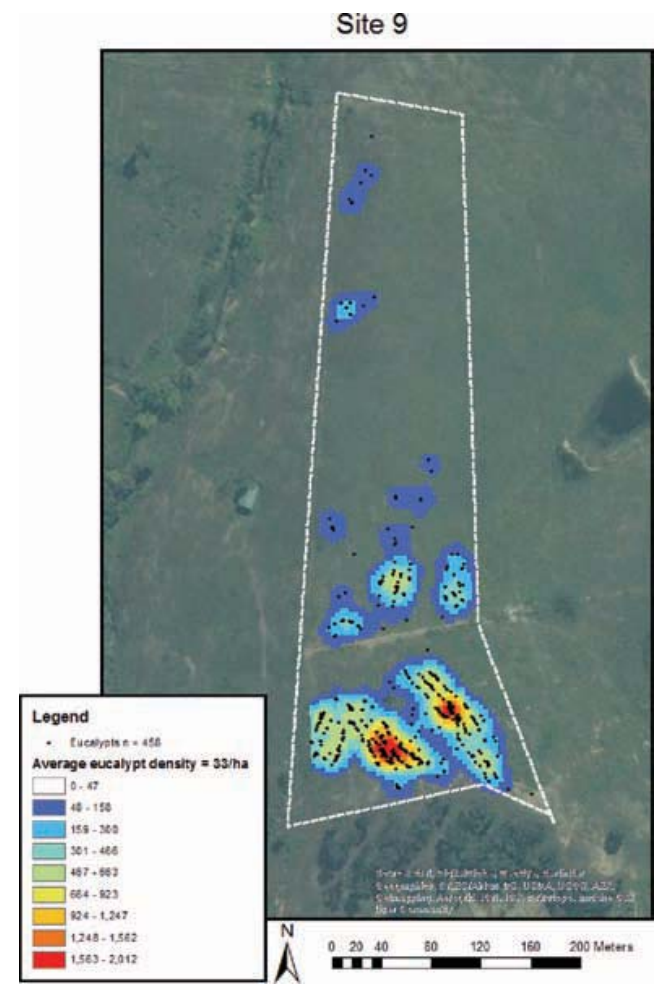

FIGURE 14. Site 9 is 14 ha in size, had an average density of 33 eucalypts/ha, and a range of o-2,012 eucalypts/ha.

We also hypothesised that position along the slope may also explain some of the variation in tree density. However, there was no consistent effect of position of each belt along a slope. In some sites there were more trees at the top of a slope, other sites more trees at the bottom, and yet other sites there appeared to be no influence of slope.

Perhaps more eucalypt trees established at those sites where more eucalypts seed was sown. But no, there was no relationship between total amount of seed sown in each paddock and the total number of eucalypts found.

\section{Is it good?}

Another question was, is this highly variable establishment of long-lived eucalypt trees 'good'? Will this variable density of trees be enough? But good to whom? Enough for whom?

Remember, the cost of the direct seeding was paid for by the Australian Government, so taxpayers will likely have an interest if this programme is good value for money. So from a simple public financial investment perspective, value for money was, not surprisingly, highly variable. Based on just the cost of eucalypt seed, each established tree cost a mere I 8 cents/tree at one site, but nearly $\$ 3 /$ tree at two other 


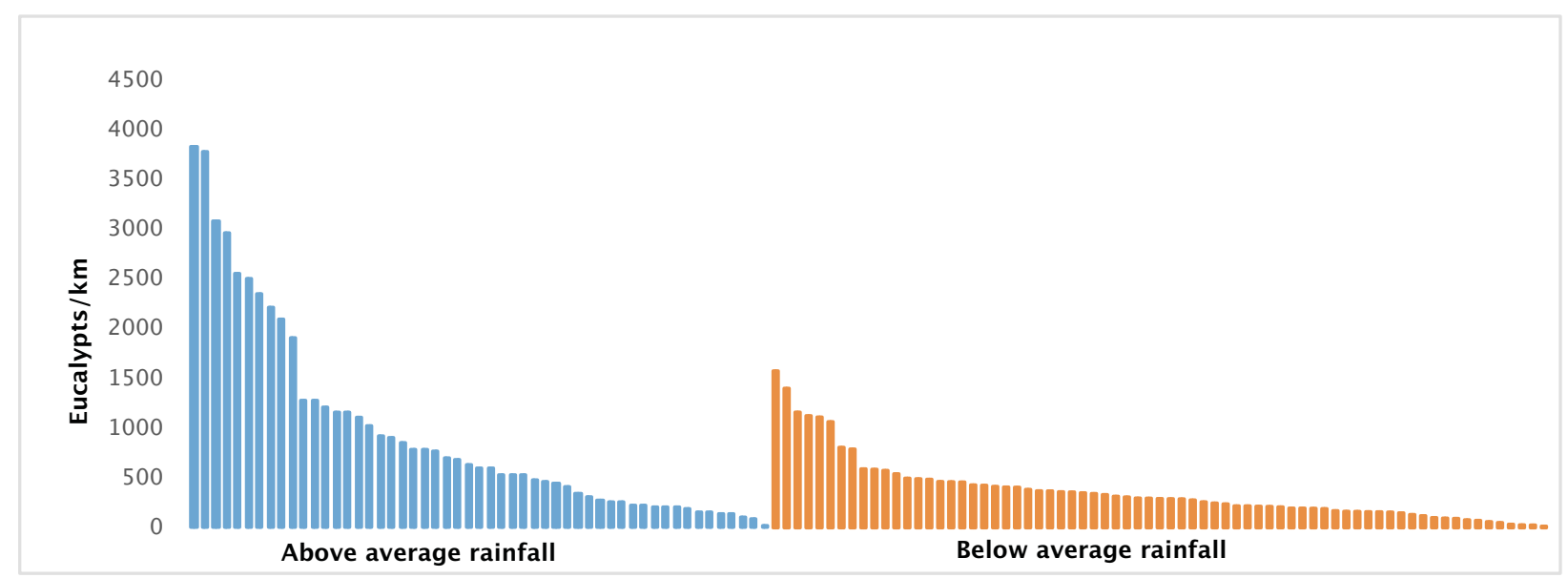

FIGURE 15. Belts that were in sites that were seeded in years of above average rainfall (blue bars) generally had a higher number of eucalypt $/ \mathrm{km}$ of direct seeding. Belts in sites that had less than the annual average rainfall in the year seeded (orange bars) clearly had fewer trees establish from direct seeding.

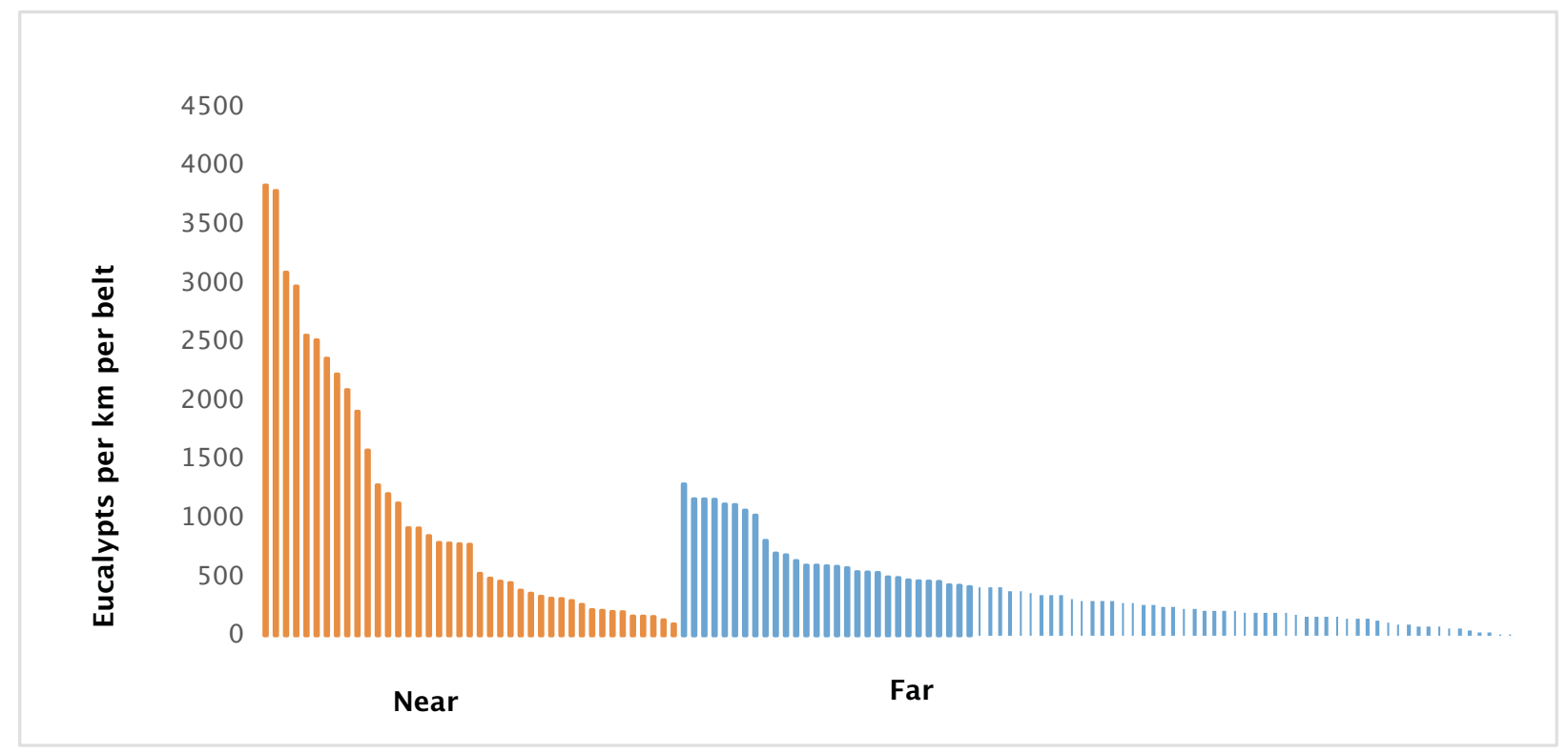

FIGURE 16. Orange bars show the density of eucalypts $/ \mathrm{km}$ in belts that established near pre-existing strips of trees, whereas blue bars represent tree density a long way from shelter. Sheltered belts clearly have a generally higher density of eucalypts than those belts hundreds of metres away from shelter.

sites and about \$I/tree at other sites (Table 2). This compares to $\$ 20-40 /$ tree if seedlings grown in nurseries are professionally hand planted and individually protected with livestock-proof fencing.

Another view on the 'Is it good?' question is from a conservation perspective. WOPR paddocks were once grassy woodlands free of chainsaws, sheep and cattle, and managed by Aboriginal peoples for thousands of years. What might these woodlands have looked like prior to clearing and grazing by farmers? Are WOPR paddocks on a trajectory to restoring the nature of pre-farming woodlands? The best we can do is find and measure the woodland structure of the few least disturbed (reference) woodlands left in the region. Conservation biologists [II] suggest a reference woodland has lots of young trees (narrow stems, 176/ha) and a scatter (less than Io/ha) of medium and large sized trees. The bad news is that WOPR paddocks have just a handful of big and old trees likely full of habitat hollows. 
TABLE 2. The estimated cost per established eucalypt per Whole of Paddock Rehabilitation (WOPR) site based just on the cost of seed (values in Australian Dollars).

\begin{tabular}{lcrrl}
\hline & $\begin{array}{l}\text { Eucalypt } \\
\text { seeds } \\
\text { sown } \\
\text { Site }\end{array}$ & $\begin{array}{l}\text { Cost of } \\
\text { seed } \\
\text { (\$/paddock) }\end{array}$ & $\begin{array}{l}\text { Total } \\
\text { number of } \\
\text { eucalypts }\end{array}$ & $\begin{array}{l}\text { Cost }(\$) \\
\text { per eucalypt } \\
\text { tree }\end{array}$ \\
\hline 1 & 2,508 & 1,003 & 5,543 & 0.18 \\
2 & 3,600 & 1,440 & 2,869 & 0.5 \\
3 & 2,248 & 899 & 2,476 & 0.36 \\
4 & 3,990 & 1,596 & 1,432 & 1.11 \\
5 & 3,680 & 1,472 & 1,127 & 1.31 \\
6 & 1,924 & 770 & 871 & 0.88 \\
7 & 5,105 & 2,042 & 767 & 2.66 \\
8 & 3,960 & 1,584 & 533 & 2.97 \\
9 & 3,377 & 1,351 & 458 & 2.95 \\
\hline Mean & 3,377 & 1,351 & 1,786 & 1.44 \\
Standard & 942 & 377 & 1,547 & 1.06 \\
deviation & & & & \\
\hline
\end{tabular}

The good news is that most WOPR paddocks have at least small patches of over 200 young trees/ha and many of them will hopefully survive to a grand old age riddled with hollows.

However, the most important perspective on this 'Is it good?' question comes from the farmers who own and manage their WOPR paddocks. At the beginning of her field work Miriam interviewed all the farmers (men and women) in depth about their feelings towards their WOPR paddocks. She was then able to follow up with some of the farmers regarding their reaction to her research findings. They were all very positive with the changes they were seeing across their WOPR paddocks. Their reasons for thinking WOPR paddocks are 'good' are many and demonstrate the wide range of values they get from their paddocks. It's well worth reading the interview quotes provided in Boxes $\mathrm{I}-5$.

This quote is typical of the many values farmers gain from their WOPR paddock:

Just, that you've got to have a balance of everything. You can't just have grass; you've got to have trees, you've got to have conservation areas because everything works all in together. You've got to have habitat for your animals, and all the natives.... And it's much more pleasant when you go out to work in the paddocks when you've got trees around and there's shelter and it's just... relaxing. That's my pearls of wisdom.

\section{NEXT CHALLENGE-GETTING BIGGER}

We conclude that WOPR is working-keystone eucalypts are being returned at a modest cost to near treeless landscapes for the first time in I5O years. Critically, the farmers involved are seeing lots of values from their paddocks that are now just old enough to once again be grazed for wool and meat production. The scale of these tree plantings is finally at the operational (management) scale of entire paddocks. This scale is required to address the tree decline crisis in Australia. These paddocks are now big enough to provide valuable habitat to wildlife dependent on grassy woodlands. These paddocks are big enough to greatly reduce the risk of dryland salinity and poor water quality entering creeks, rivers, and dams. But there is not enough of them. WOPR is not self-funding-it remains dependent on taxpayer (government) support. Every farmer needs a few WOPR paddocks, but few can afford them without external support. This could cost billions of dollars. Who should pay? We the consumers of fine wool and tasty lamb chops?

\section{CASE STUDY QUESTIONS}

I. Is this approach to integrating conservation and farming applicable to the agricultural landscapes that you, as a food consumer, are dependent upon? 
BOX 1. Quotes from the farmers demonstrating that they value shelter provided by trees for livestock, particularly lambs.

Good paddocks are those that have somewhere to protect whatever you put on the property. (Farmer B)

Yeah, because trees create a lot of shelter. (Farmer E)

The stock use energy to keep warm and cold. So on a hot day they've got to cool down and they're using energy to do that, whereas if I've got shade. . . And cold days, obviously a break from the wind, on cold wet days. (Farmer J)

So we had II6\% lambing, which I think is the best we've ever had. You could leave here in the morning and it would be just freezing, and go up there to check out the sheep and we won't say the conditions were balmy, but it was just noticeably more pleasant, or much less unpleasant there. (Farmer G)

Box 2. Quotes from the farmers demonstrating that they value shelter provided by trees for native wildlife.

So the idea then was to make a corridor, principally for birds, but potentially for sugar gliders and things that are there, give them an opportunity to go through. (Farmer E)

But I do enjoy seeing the birdlife. And I have noticed the birdlife; more birds and a bigger variation. And especially the small birds, they're really back into the landscape. (Farmer D)

For every other tree that's been killed, they have to nest somewhere. ... And again, it's good for the small birds. The wild canaries that are out the back now-magic. Ten years ago there wouldn't have been any; now there's mobs of 30 or 40 canaries going around. Plus the thrushes that are out there. Thrushes usually love to be around a house, but I was out there the other day and there were a few thrushes, talking one to another. (Farmer C)

BOX 3. Quotes from farmers demonstrating that they value the cultural ecosystem services provided by trees. And we love all the gums, like the stringy barks are beautiful, and the bottle brush, and it's just beautiful. (Farmer I) And we just started planting trees and saw the benefits of that. Both stock wise, salt wise, and just general beautification of the place; the aesthetics of it. (Farmer J)

And at the same time, try to sort of, make a contribution to the overall environment. (Farmer F)

Because we're harnessing what Mother Nature's given us, and it's complementing what we're doing. (Farmer D)

But I think that an appreciation of trees, it brings another dimension of enjoyment-this is a bit philosophicalbut another dimension of enjoyment in life. I dunno what it is . . but there's something about a belief in God, or a belief in something, a belief in trees, the fact that you believe in trees, have faith in trees, it virtually takes you back to the humbleness of the whole-of how pathetic we really are as humans, human beings are. . . (Farmer C)

BOX 4. Quotes from farmers demonstrating that they value the regulatory ecosystem services provided by trees.

I think another benefit, because you know the little birds eat insects-the Christmas beetles might be attacking all the trees, but you know the little birds are eating those .... (Farmer C)

And in fact, if you've got timber on the tops of the hills all the leaf matter and rubbish that drops onto the ground sort of seeps its way down into the valleys and really - I think it's sort of a natural way of ... of fertilising the country, really. (Farmer E) 
BOX 4. Continued

But then the trees help keep the moisture down, the grass keeps-the grass is a fantastic pump too. And that's what drove us to trees in the first place, the salt. (Farmer J)

Well, to me, putting tree lots around on the place is improving it. (Farmer K)

BOX 5. Farmers were unanimously happy with their WOPR paddocks and with WOPR generally.

... regardless of the result I think that it's a great program, and I think that it's a really worthwhile spend of time and spend of money. (Farmer A)

And it adds value to your asset as well. . your loss of production in the short term is increased three or fourfold, because of the fact that you might have had a hundred sheep in there before you put the trees in, once you put the trees in ... you've increased productivity. I can put Iso lambing ewes into that [WOPR] paddock now, where before I wouldn't put unshorn sheep in it. You've increased productivity much more than locking up a paddock for three years! (Farmer C)

But still, it's better than what it was. So I'm happy. (Farmer D)

Ah well, from my point of view I think it's been a great success, the paddock we've done, I'm really pleased with it. I'm pleased the way the trees have got away and really, it's no effort is it, really? I mean, apart from the very initial bit of slashing and spraying getting ready for them to come, that is. And it takes no time at all for them to sow it. Like, it's extraordinary. They did that whole hill before lunch! (Farmer E)

I'm really pleased with it, with how it's going, it's doing very well. (Farmer F)

It's been very pleasing really. (Farmer $\mathrm{G}$ )

Really loved being involved in this process and really keen to hear all the results. It's very, very exciting. Very, very cool. (Farmer I)

And I just - the program's great, you know, with the fact that you're leaving strips in between: it's good protection, and still grass grows, and everything else... I haven't lost any grazing, really. One lot of corridors I grazed through some bad drought years.... So that's just a bonus if I need it, it's up my sleeve. (Farmer J)

Been very happy with it, and I still plant some tubestock, but mainly the direct seeding has been the way to go. (Farmer $\mathrm{K}$ )

2. Why do you think this approach has been so successful? How do you define success?

3. How much more would you be willing to pay for farm produce (food and fibre) that comes from such wildlife-friendly and livestock kind farms? Based on a $\$ 100$ worth of groceries in your shopping cart, are you willing to pay another \$10 or $\$ 20$ ?

4. Should such sustainable farming practices and wildlife-friendly plantings be mandatory or voluntary? Should just the farmer bear the cost, or taxpayers, or consumers too?

5. You'll see from the GIS 'heat-maps' of eucalypt tree density (Figures 6-I4) that the density of young eucalypt trees is highly variable. Is this patchy establishment good? What do you think are the advantages and disadvantages of such patchy tree establishment? Would it have been better to plant nursery grown seedlings evenly spaced rather than rely on directly sown seeds? These are tough questions Greening Australia, who facilitates these plantings, debates on a regular basis.

6. A general critique of projects like this is that it is unlikely to restore endangered grassy eucalypt woodlands to high conservation status found on lands never developed for agriculture. Given a rapidly changing and increasingly hostile climate, is WOPR an appropriate approach to conservation? Assuming that we have entered the 
Anthropocene, how can we sustainably manage agricultural landscapes and maintain native biodiversity?

\section{AUTHOR CONTRIBUTIONS}

Miriam Adams-Schimminger was the investigator who led all the field work, conducted all the interviews with landowners, conducted the data analyses, and wrote the Honours thesis on which this case study paper is based.

Graham Fifield was Miriam's co-supervisor, assisted with project administration, particularly with arranging access to field sites, and had input into the conceptualisation of this research project. He also provided review and editing of earlier drafts of this paper.

Bruce Doran provided the suggestion of visualising the data with heat maps and assisted in the technical preparation of these maps.

David Freudenberger was Miriam's academic supervisor and assisted in the conceptualisation of the research. He took the lead in writing up this case study based on Miriam's thesis.

\section{ACKNOWLEDGEMENTS}

We are indebted to the farmers who participated in this study. We are so grateful for their time, insights, patience, tea and biscuits, and access to their paddocks. We say a huge thank you to Fehin, Jen, and David for their invaluable help with fieldwork when the cattle were too intimidating, the weather too hot, or it all just seemed too much. Additional thanks to Fehin for help with designing a method to manage and analyse the spatial data.

\section{FUNDING}

This study would not have been possible without a generous scholarship from the Capital Region Landkeepers Trust. The Trust is committed to enhancing innovative landscape action, scholarship, and education in the Capital Region. This research was also supported by funding from the Fenner School of Environment and Society, Australian National University.

\section{COMPETING INTERESTS}

Graham Fifield is an employee of Greening Australia. David Freudenberger was the Chief Scientist for Greening
Australia (2007-2012) and is currently a Senior Lecturer at the Australian National University (ANU). Bruce Doran is also a Senior Lecturer at ANU.

\section{SUPPORTING INFORMATION}

PowerPoint presentation titled 'Getting Eucalypts into Paddocks: Is Whole of Paddock Rehabilitation working?'

\section{REFERENCES}

I. Gibbons, P. and Boak, M. 2002. The value of paddock trees for regional conservation in an agricultural landscape. Ecological Management \& Restoration, 3(3): 205-210.

2. Fischer, J., Stott, J., Zerger, A., Warren, G., Sherren, K. and Forrester, R.I. 2009. Reversing a tree regeneration crisis in an endangered ecoregion. Proceedings of the National Academy of Sciences of the United States of America, 106(25): 10386-10391.

3. Gibbons, P., Lindenmayer, D.B., Fischer, J., Manning, A.D., Weinberg, A., Seddon, J., Ryan, P. and Barrett, G. 2008. The future of scattered trees in agricultural landscapes. Conservation Biology, 22(5): 1309-1319.

4. Fischer, J., Stott, J. and Law, B.S. 2010. The disproportionate value of scattered trees. Biological Conservation, I43(6): 1564-1567.

5. Williams, A.N. 2013. A new population curve for prehistoric Australia. Proceedings of the Royal Society B, DOI: 10.1098/ rspb.2013.0486

6. Salt, D. 2016. A brief history of agri-environment policy in Australia: from community-based NRM to market-based instruments. In Ansell, D., Gibson, F. and Salt, D., editors. Learning from Agri-environment Schemes in Australia, ANU Press, Canberra. Available: http://press.anu.edu.au?p=346093.

7. Ansell, D.H., Fifield, G., Munro, N., Freudenberger, D. and Gibbons, P. 2016. Softening the agricultural matrix: a novel agri-environment scheme that balances habitat restoration and livestock grazing. Restoration Ecology, 24, I59-164.

8. Lindenmayer, D.B., Northrop-Mackie, A.R., MontagueDrake, R., Crane, M., Michael, D., Okada, S. and Gibbons, P. 20I2. Not all kinds of revegetation are created equal: revegetation type influences bird assemblages in threatened Australian woodland ecosystems. PLoS ONE, 7(4): e34527.

9. Gibbons, P. and Lindenmayer, D. 2002. Tree Hollows and Wildlife Conservation in Australia, CSIRO Publishing, Melbourne.

Io. Carlos, H.A., Shi, X., Sargent, J., Tanski, S. and Barke, E. 2010. Density estimation and adaptive bandwidths: a primer for public health practitioners. International Journal of Health Geographics, 9(39).

II. Gibbons, P., Briggs, S.V., Murphy, D.Y., Lindenmayer, D.B., McElhinny, C. and Brookhouse, M. 20ı. Benchmark stem densities for forests and woodlands in south-eastern Australia under conditions of relatively little modification by humans since European settlement. Forest Ecology and Management, 260(I2): 2125-2133. 